\title{
Amelioration of C - Reactive Protein and Lectin Like Oxidised Low Density Lipoprotein Receptor Complex Induced Endothelial Dysfunction by Oligomeric Proanthocyanidins.
}

\section{Sankar Jamuna}

University of Madras School of Life Science

Rathinavel Ashokkumar

University of Madras - Guindy Campus

Niranjali Devaraj Sivasithamparam ( $\sim$ profniranjali@gmail.com )

University of Madras - Guindy Campus https://orcid.org/0000-0001-6371-8552

\section{Research Article}

Keywords: OxLDL, CRP, OPC, Endothelial dysfunction, Inflammation

Posted Date: August 31st, 2021

DOl: https://doi.org/10.21203/rs.3.rs-770001/v1

License: (c) (1) This work is licensed under a Creative Commons Attribution 4.0 International License.

Read Full License 


\section{Abstract}

C-reactive protein (CRP) is a well established biochemical marker for atherosclerosis. Inflammation induced by CRP promotes endothelial dysfunction. Modification of LDL inside the artery wall favors the elevation of this acute phase protein. The mechanism of OxLDL+CRP complex is unrevealed so far. Hence, this mechanism was considered as the important factor to trigger the monocyte to macrophages differentiation which in leads to foam cells formation. Hence this key event should be targeted and focused on how this complex (OxLDL+CRP) proceeds to endothelial dysfunction. OPC is a well known cardioprotective flavon-3-ols. The present study is challenged between the protective roles of OPC against the deleterious effect of this complex (OxLDL+CRP) on endothelial cells. Monolayer of Endothelial cells were incubated with THP-1 monocytes for $48 \mathrm{~h}$ supplemented with OxLDL $(10 \mathrm{mg} / \mathrm{ml})+\mathrm{CRP}(10 \mathrm{mg} / \mathrm{ml})$ complex and treated with OPC $(100 \mathrm{mg} / \mathrm{ml})$. Morphological changes, cell migration assay and capillary tube forming assay was carried out. Myeleoperoxidase levels were estimated to determine the adhesion of monocytes onto EC monolayer. RT-PCR analysis of L-Selectin was done. The quantification of NO levels and analysis of mRNA expressions of eNOS is to determine the nitric oxide demand caused due to OxLDL+CRP complex. LOX-1, scavenger receptor levels were analysed by mRNA expression.

Proinflammatory markers such as IL-6, MCP-1 and IL-1b were studied. Accumulation of ROS levels were measured fluorimetrically using DCF-DA. Spectrophotometric analysis of Sirius red dye binding collagen levels was observed. Mitochondrial membrane potential was determined by JC- 1 dye and cell cycle analysis was done by FACS analysis. Protein - Protein docking was carried out between CRP and LOX-1. This docked protein complex were again docked with OPC and atrovastatin to show the inhibitory mechanism of CRP binding with LOX-1. OPC showed a promising inhibitory mechanism against OxLDL+CRP complex. To emphasis the results OPC treated group showed decreased levels of proinflammatory markers, LOX-1 and L-Selectin levels. Endothelial nitric oxide levels were increased upon OPC treatment and reduction in the ROS levels. Endothelial cells apoptosis was prevented by OPC.

Docking studies showed that in the absence of ligands (OPC) binding of CRP and LOX-1 was greater and vice versa in the presence of ligands. To conclude, OxLDL + CRP complex inhibitory effects of OPC could maintain the normal homeostasis.

\section{Highlights}

- Accumulation of OxLDL triggers inflammatory phase during atherosclerosis by elevating the acute phase protein- $C$ reactive protein.

- Increased levels of CRP and OxLDL could initiate the endothelial dysfunctions via CRP-LOX 1 complex.

- Oligomeric proanthocyanidins isolated from Crataegus oxyacantha berries inhibits the binding of CRP-LOX-1 complex; possess anti-angiogenic and anti-inflammatory effects.

\section{Introduction}


The development of atherosclerosis and intraplaque instability was directly correlated with elevated levels key inflammatory proteins [1,2]. C-reactive protein (CRP) is a prototypic inflammatory marker and biochemical marker to predict the condition of atherosclerosis induced myocardial infarction [3,4]. Monocytes trigger the production of inflammatory cytokines and enhance the adhesion onto endothelial cells during inflammatory conditions [5,6]. Harmon et al. (2016) has been suggested that CRP and OxLDL are considered as conventional biomarkers for CVD [7]. Recently it has been reported that CRP binds to oxidized low density lipoprotein (OxLDL), thereby promotes monocyte/ macrophage differentiation [8]. CRP colocalizes with OxLDL and macrophages in the human atherosclerotic plaque and initiates the intraplaque burden [9]. The CRP enhances the LOX-1 expression and leads to endothelial dysfunction [10].

Our laboratory researchers have explored the anti-oxidant, anti-inflammatory, anti-lipid peroxidation effects, inhibition of modification of lipoproteins, hepatoprotective and cardioprotective effects of Oligomeric proanthocyanidins complex (OPC) isolated from Crataegus oxyacantha berries for past two decades [11-16]. Recently, Ashokkumar et al., (2018) [17] showed that supplementation OPC protects the isoproterenol induced infarcted rats. Oral supplementation OPC regulates the impaired cholesterol metabolism upon CC diet induced atherosclerosis upon regulating the HMG- CoA levels [18]. Another study from our laboratory showed the reestablishment of impaired cholesterol efflux in foam cells, upon OPC treatment activation of autophagic signaling mechanisms with improved cholesterol efflux from foam cells, which proved the anti- atherosclerotic effects of OPC [19].

Previous studies have emphasized on the inflammatory effects of CRP and OxLDL alone. However, CRP and OxLDL together involved in triggering the endothelial dysfunction which further leads to initiation of inflammatory signaling cascades. To date, studies on the deleterious effect of CRP and OxLDL together was elusive. Hence, this present study hypothesized to identify the inflammatory response of CRP and OxLDL-induced endothelial dysfunction mediated by LOX-1, MCP-1, IL- 6 and potential inhibitory effects of OPC upon these inflammatory markers. Therefore, we have carried out both in silico and in vitro approaches to mimic the interaction between CRP-LOX1 complex in the presence of OxLDL and promising inhibitory effects of OPC against OXLDL induced CRP-LOX1 complex.

\section{Experimental Methods}

\section{In silico studies}

\section{Optimization of protein for docking studies}

The X-ray crystallographic structures of human C- reactive protein (PDB ID: 1GNH) and Lectin like Oxidised LDL receptor- 1 (PDB ID: 1YXK) were obtained from the Protein Data Bank. Potential active site residues of CRP and LOX 1 were identified using CastP server [20]. CASTp server uses the weighted Delaunay triangulation and the alpha complex for shape measurements.

\section{Preparation of Ligands}


The monomers of Oligomeric proanthocyanidins such as Epigallocatechin gallate, Gallocatechin, Gallocatechingallate, Procyanidins, Proanthocyanidins, Proanthocyanidin B2-0 gallate were downloaded as .sdf files from Pubchem. All the ligand structures were drawn using Chemdraw software and converted into PDB format (.pdb) using Open Babel tools [21].

\section{Protein-protein interaction CRP-LOX1 complex}

Protein - Protein interactions of CRP and LOX1 was carried out using patch dock server. This will perform steric clashes test to remove conformations that result in steric clashes between the receptor and ligands $[22,23]$. The parameters used for docking process with Patch Dock were: Clustering RMSD-4.0. The following parameter should be followed: Complex type-set as default. The interaction was visualized using Discovery Studio Visualizer is an online freeware (http://accelrys.com/).

\section{Molecular Docking}

The molecular interaction analysis was done as followed by method described by Sankar et al., (2018) [18]. The CRP- LOX 1 complex and ligands were loaded into docking server to analyses the binding efficiencies of OPC monomers by inhibiting the LOX-1 interaction.

Based on the in silico studies, the CRP-LOX 1 complex inhibitory effects of OPC were further confirmed from in vitro analysis.

\section{In vitro studies}

\section{Isolation of OPC and confirmation}

Crataegus oxyacantha berries were purchased from Herrings Pharma (Pondicherry, India). OPC were isolated and confirmed by vanillin $\mathrm{Hcl}$ method $[16,18]$.

\section{Cell culture and maintenance}

ECV304 - Human vascular endothelial cell lines were obtained as a gift from Dr. Suvro Chatterjee, Vascular biology lab, AU-KBC research centre, Anna University, Chennai. THP-1 cells procured from NCCS (Pune, India). ECV-304 cells were maintained with DMEM supplemented with $10 \%$ FBS, antibiotic and grown in $5 \% \mathrm{CO}_{2}$ atmosphere at $37^{\circ} \mathrm{C}$. THP-1 cells were maintained in RPMI supplemented with $10 \% \mathrm{FBS}$, antibiotic and grown in $5 \% \mathrm{CO}_{2}$ atmosphere at $37^{\circ} \mathrm{C}$. The cells were counted with a hemocytometer, and the number of viable cells was determined by trypan blue dye exclusion.

\section{LDL isolation and modification}

Human native-LDL ( $\mathrm{nLDL}, d=1.019-1.063 \mathrm{~g} / \mathrm{ml}$ ) was isolated from plasma, obtained from Volunteer Health Services (VHS), Chennai, Tamil Nadu, India., by sequential gradient ultracentrifugation methods as described previously by Jamuna et al., (2017) [24]. 


\section{Assessment of Cell viability}

MTT assay was carried out for THP- 1 cells and ECV-304 cells at coculture conditions. Endothelial cells were seeded at a concentration of $1 \times 10^{4}$ cells/well in 96 well plates and after 24 hrs THP $-1\left(1 \times 10^{4}\right.$ cells/well)was added. This condition was to mimic the direct interaction of monocytes upon endothelial cells as in Invivo conditions. Different concentrations of OPC $(10,25,50,75,100,125,150,175$ and $200 \mu \mathrm{g} /$ $200 \mu \mathrm{l}) ; \mathrm{OxLDL}$ and $\mathrm{CRP}(5,10,15,20,25 \mu \mathrm{g} / 200 \mu \mathrm{l})$ were added. The plates were then incubated at $37^{\circ} \mathrm{C}$ and supplemented with $5 \% \mathrm{CO}_{2}$ for 24 and $48 \mathrm{~h}$. At the end of incubation period, $25 \mu \mathrm{l}$ of a MTT stock solution $(5 \mathrm{mg} / \mathrm{ml})$ : growth medium at a ratio of $1: 1$ was added directly to each well and the plates incubated for 5 hours in dark conditions. The plates were then centrifuged at $400 \times \mathrm{g}$ for $10 \mathrm{~min}$. After 10 min, the supernatants were removed from all the wells and reduced MTT dye in each well was solubilized with $100 \mu \mathrm{l}$ of DMSO and absorbance was determined at $570 \mathrm{~nm}$ using an ELISA plate reader. Subsequently, the absorbance was determined at $550 \mathrm{~nm}$. Percentage of viability was calculated using the formula: \% Viability $=(O D$ test $/ O D$ control $) \times 100$.

\section{Experimental groupings}

Based on the MTT assay, the non-toxic concentration for CRP, OxLDL and OPC were fixed and proceed with experimental groupings as follows:

\begin{tabular}{lll} 
Group I & $:$ ECV304 cells + THP-1 cells (Coculture) \\
\hline Group II & $:$ ECV304 cells + THP-1 cells +OxLDL $(10 \mu \mathrm{g} / \mathrm{ml})+$ CRP $(15 \mu \mathrm{g} / \mathrm{ml})$ \\
\hline Group III & $:$ & ECV304 cells + THP-1 cells + OxLDL $(10 \mu \mathrm{g} / \mathrm{ml})+$ CRP $(15 \mu \mathrm{g} / \mathrm{ml})+$ OPC $(100 \mu \mathrm{g}$
\end{tabular}

\section{Assessment of morphologic changes and quantification of adherent THP-1 cells on ECV-304 cells}

Morphological changes of ECV304 and THP-1 cells were visualized under microscope to determine the adhesion of THP-1 cells onto the monolayer of endothelial cells induced with OxLDL and CRP.

\section{Monocytes Myeloperoxidase activity}

THP- 1 cells $\left(1 \times 10^{5}\right)$ were added onto the monolayer of ECV-304 cells to initiate the adhesion. After $48 \mathrm{~h}$, non-adherent monocytes were removed by washing the cells with gently PBS (pH 7.4). Monocyte adhesion onto endothelial cells was quantified by measuring the monocyte myeloperoxidase (MPO) activities as previously described by Kumar et al. (2002) [25].

\section{Quantification of Nitric Oxide}

Nitrite production, an indicator of NO production, was measured in the conditioned culture medium by the Griess reaction. After the experimental period, conditioned medium was collected for quantification of 
nitrite levels. Briefly, $100 \mu \mathrm{L}$ of conditioned medium were mixed with $100 \mu \mathrm{L}$ of Griess reagent (equal volumes of $1 \%(\mathrm{w} / \mathrm{v})$ sulphanilic acid in $30 \%(\mathrm{v} / \mathrm{v})$ acetic acid and $0.1 \%(\mathrm{w} / \mathrm{v}) \mathrm{N}-(1$-naphthyl) ethylenediamine in $60 \%(\mathrm{v} / \mathrm{v})$ acetic acid), incubated at RT for $30 \mathrm{~min}$ in the dark, and the absorbance at $540 \mathrm{~nm}$ was measured spectrophotometerically. The amount of nitrite was calculated from a standard curve using freshly prepared sodium nitrite in culture medium.

\section{Cell Migration Assay}

To assess the cell migration, the "scratch" wound assay was carried out (). Briefly, ECV-304 cells were grown on $6 \mathrm{~cm}$ dishes previously labeled with a traced line. The cell monolayer was scraped with a disposable rubber policeman to create a cell-free zone. Thereafter, cells were washed with medium and induced with CRP + OxLDL and treated with OPC. EC migration was quantified by measuring the width of the cell-free zone (distance between the edges of the injured monolayer) before and after $48 \mathrm{~h}$ stimulation using a computer-assisted inverted microscope.

\section{Capillary Tube Formation Assay}

The tube formation assay was done to investigate the effects of OxLDL+ CRP on angiogenesis in in vitro conditions as described previously by Zhang et al., (2006). In briefly, a 96-well plate was coated with $2 \%$ gelatin / well, which was allowed to solidify at $37^{\circ} \mathrm{C}$ for $45 \mathrm{~min}$. ECV-304 cells were seeded at a density of $3 \times 10^{4}$ cells/well along with OxLDL + CRP and OxLDL +CRP +OPC or vehicle (control), then $100 \mu \mathrm{l}$ of serum-free medium was added. Plates were incubated for $48 \mathrm{~h}$ at $37^{\circ} \mathrm{C}$ and $5 \% \mathrm{CO}_{2}$ and images were recorded by an inverted microscope (Olympus, IX70, Japan), and total number of tubes formed were counted and analysed.

\section{Flow cytometry analysis}

The effect of CRP + OxLDL and co treated with OPC on coculture model was analysed for changes in cell cycle was studied by propidium iodide stained flow cytometry analysis. After the experimental period cells were fixed using $70 \%$ ethanol and stored for overnight at $4^{\circ} \mathrm{C}$. The fixed cells were washed with $1 \mathrm{X}$ PBS and stained with propidium iodide for FACS analysis. Cell cycle analysis was performed using BD Biosciences FACS Calibur. The data were analysed using Multicycle software (Phoenix Flow Systems, San Diego, CA).

\section{Determination of ROS Production}

The intracellular ROS production was analysed using the flurescent dye 2', 7'-dichlorofluorescin diacetate. This method measures the intracellular ROS such as hydrogen peroxide $\left(\mathrm{H}_{2} \mathrm{O}_{2}\right)$, hydroxyl radical, and hydroperoxides. Briefly, after the experimental period cells were washed twice with PBS and incubated with $5 \mu \mathrm{M}$ of DCF-DA cells, then incubated at $37^{\circ} \mathrm{C}$ for $30 \mathrm{~min}$. The fluorescence intensity was measured at $530 \mathrm{~nm}$ after excitation at $480 \mathrm{~nm}$ using spectrofluorimeter. The increase in fluorescence intensity was used to assess the generation of net intracellular ROS. 


\section{Determination of $\Delta \Psi_{\mathrm{m}}$}

Mitochondrial membrane potential $(\Delta \psi)$ was analyzed by using JC-1 fluorescence. Briefly, cells were incubated for $10 \mathrm{~min}$ in the dark with $0.5 \mathrm{ml}$ of $\mathrm{JC}-1$ ( $20 \mathrm{mg} / \mathrm{ml}$ in PBS), washed, and suspended in $0.5 \mathrm{ml}$ of PBS for fluorescent activated cell sorting (FACS) analysis and also the fluorescence emission of JC-1 was measured at wavelengths corresponding to its monomer $(530 \pm 15 \mathrm{~nm})$ and $J$ aggregate $(>590 \mathrm{~nm})$ forms. Fluorescence was measured in a fluorescent plate reader.

\section{mRNA analysis by semi-quantitative RT-PCR}

At the end of the treatment, RNA was extracted using Trizol Reagent (Medox) according to the manufacturer's protocol. The RNA concentration was quantified by Biophotometer (Eppendrof, Germany). cDNAs were synthesized from RNA using M-MLV reverse transcriptase (GeNeiTM, Bangalore). Specific primer sequences (Table 1) were used to amplify gene transcripts. The reaction was amplified in a thermal cycler (Eppendrof, Germany). The PCR conditions were for $5 \mathrm{~min}$ of initial denaturation at $94^{\circ} \mathrm{C}$ and 35 cycles consisting of $94^{\circ} \mathrm{C}$ for $30 \mathrm{sec}$; annealing at respective Tm (Table 1) for $30 \mathrm{sec}$; elongation at $72^{\circ} \mathrm{C}$ for $1 \mathrm{~min}$ and final extension at $72^{\circ} \mathrm{C}$ for $10 \mathrm{~min}$. The amplified products $(10 \mu \mathrm{l})$ were electrophoresised on $1.5 \%$ agarose gel with ethidium bromide and visualized under UV light.

\section{Statistical analysis}

Data were expressed as Mean \pm S.D and statistically evaluated using one way ANOVA (SPSS v 16.0). The statistical significance was calculated according to the Student't'-test and probability values ( $p$ value). $p$ values of $<0.05$ were considered to indicate statistical significance. 
Table 1: Details of Primers, Tm, and size of amplicon used in this study

\begin{tabular}{|c|c|c|c|}
\hline Gene & Sequence $\left(5^{\prime}-3^{\prime}\right)$ & $\operatorname{Tm}\left({ }^{\circ} \mathrm{C}\right)$ & $\begin{array}{l}\text { Product size } \\
\text { (bps) }\end{array}$ \\
\hline \multirow[t]{2}{*}{ LOX-1 } & ААСТСТTСТСААСТСТGT & \multirow[t]{2}{*}{51.4} & \multirow[t]{2}{*}{425} \\
\hline & GATGGATATGTTCACTCTC & & \\
\hline \multirow{2}{*}{$\begin{array}{l}\text { L- } \\
\text { Selectin }\end{array}$} & GACTTACCATTATTCTGA & \multirow[t]{2}{*}{46.3} & \multirow[t]{2}{*}{177} \\
\hline & САТАТТССТССТАТСТTС & & \\
\hline \multirow[t]{2}{*}{ MCP-1 } & ACTTGTAGGCATTATCTA & \multirow[t]{2}{*}{48.0} & \multirow[t]{2}{*}{238} \\
\hline & TTAGGATGAACTGGATTA & & \\
\hline \multirow[t]{2}{*}{ IL-6 } & GCACCTCAGATTGTTGTT & \multirow[t]{2}{*}{57.7} & \multirow[t]{2}{*}{256} \\
\hline & GCATAGCCACTTTCCATT & & \\
\hline \multirow[t]{2}{*}{ eNOS } & AAGTTGGAATCTCGTGAA & \multirow[t]{2}{*}{57.5} & \multirow[t]{2}{*}{145} \\
\hline & AAGGCTGTAGGTTATATGG & & \\
\hline$\beta$-actin & $\begin{array}{l}\text { GACGACATGGAGAAAATCTG } \\
\text { ATGATCTGGGTCATCTTCTC }\end{array}$ & 133 & 57.3 \\
\hline
\end{tabular}

\section{Results And Discussion}

\section{Molecular interaction between CRP-LOX 1 complex and Ligands}

Figure 1(a) \& (b) illustrates the 3D structure of CRP and LOX 1 . The active sites of CRP and LOX 1 were predicted using CASTp as shown in figures 1 (c) \& (d). The protein-protein interaction of CRP-LOX1 was carried out using patch dock server and that complex was uploaded in molecular docking server tools. From the results, the CRP-LOX-1 complex was disrupted by the loss of binding site for LOX-1, since OPC monomers occupies that binding onto CRP. Thereby, from the results it was suggestive that OPC could alter the structural confirmation of CRP at the site $\mathrm{Ca}^{2+}$ ions per subunit. We performed this protein protein-ligand interaction for the first time to illustrate the inhibitory effects of OPC against CRP-LOX1 complex (Figure (e, $f \& g$ ). The molecular docking study was carried out using lead compounds from $C$. procera with CRP revealed their anti-analgesic and anti-inflammatory effects [28]. Previous study showed the molecular interactions between strongest interactions of statins with CRP as compared to the standard ligand phosphocholine [29]. Another recent study of Shakour and his group of researchers have revealed the possible molecular interactions between polyphenol curcumin and its derivatives with CRP exhibits the plausible anti-inflammatory and anti-oxidative against diseases [30]. Therefore, OPC could readily inhibit the CRP-LOX1 complex and improves the biological activities. Based on this in silico results, this study extended to in vitro methods to prove the anti-inflammatory properties of OPC. 
The non-toxic concentrations of OPC, OxLDL and CRP on coculture model of ECV 304 cells with THP-1 cells were determined by MTT assay. This cell viability assessment was done in three different environments to fix non-toxic concentrations of OPC, OxLDL and CRP for $24 \mathrm{~h}$ and $48 \mathrm{~h}$. The figure 2(a) illustrates the MTT assay for coculture model of ECV 304 cells with THP-1 cells induced with varying concentrations of CRP $(5-25 \mu \mathrm{g} / \mathrm{ml})$ showed $>60 \%$ of viability till $48 \mathrm{~h}$. Subsequently, the cytotoxicity of OxLDL (figure 2(b)) on coculture model of ECV 304 cells with THP-1 cells was assessed with different concentrations of OxLDL ranging for $5-25 \mu \mathrm{g} / \mathrm{ml}$ of protein. The nontoxic effects of OPC on coculture of ECV 304 cells with THP-1 cells were carried out with various concentrations of OPC (10-200 $\mu \mathrm{g})$ as illustrated in Figure 2(c). From the result, it was observed that increasing concentration of OxLDL resulted in the loss of cell viability. Hence, we fixed $15 \mu \mathrm{g} / \mathrm{ml}$ of CRP, $10 \mu \mathrm{g} / \mathrm{ml}$ of OxLDL and OPC $(100 \mu \mathrm{g} / \mathrm{ml})$ concentration were fixed as a nontoxic concentrations to study the effects of OxLDL mediated endothelial dysfunction and its associated inflammatory signaling pathways. This concentration was used for further study to evaluate the anti-angiogenic, anti-migratory, anti-invasive and anti-apoptotic properties of OPC against CRP and OXLDL induced endothelial dysfunction.

As discussed earlier, active myeloperoxidase (MPO) is released into the vessel as a result of transendothelial migration and involved in endothelial injury, and, internalization of MPO causes oxidative damage and impairs endothelial signaling [31]. Thus, release of MPO in the serum is suggestive of its pro-inflammatory effects on vasoregulatory system [32]. The activity of MPO analysed in the control and experimental groups is represented in Figure 3(a), which showed increased MPO activity in the OxLDL treated group when compared to control. This functional MPO is responsible for the increased transendothelial migration, proinflammatory response in the coculture induced with CRP+OxLDL. Thus, OPC could effectively inhibit MPO activity. Binding of OPC with the OxLDL+CRP reduces the production of pro-inflammatory mediators.

To further confirm that OPC could efficiently inhibit the trans-endothelial migration, the mRNA expression of trans-endothelial migratory markers was analyzed. L-selectin expressed by the leukocytes plays a pivotal role in the generation of rapid and efficient immune responses during the interaction of circulating leukocytes with the vascular endothelium [33]. L-selectin has been considered as both positive and negative regulator of leukocyte activation and leukocyte recruitment [34]. There are two important and measurable properties of L-selectin; its rapid proteolysis or shedding upon cell activation, and its transition from being monomeric in the plasma membrane to being clustered, following ligand binding, which is a hallmark of downstream signalling [35]. L-selectin is specifically expressed in the monocytes and facilitates the fast rolling of leukocytes on endothelium. The expression of L-selectin was evaluated to assess the adhesion of monocytes on the surface of endothelial cells [36]. Figure 3(b), represents the L-selectin mRNA of OxLDL treated group which showed downregulation, when compared to control group. This could be because of the monocytes stimulated by OxLDL do not undergo rolling, instead tether and adhere onto the endothelial surface and eventually differentiate into macrophages. Loss of Lselectin due to shedding increases leukocyte adhesion and transmigration by increasing leukocyte exposure to the inflamed endothelium and decreasing jerkiness to promote leukocyte activation by 
outside-in signaling. In the OPC treated group, monocytes were seen floating in the medium and the adhesion was partially attenuated by OPC treatment.

ROS generation is considered as a major atherogenic factor [37], Nitric oxide (NO) regulates vascular tone and local blood flow, platelet aggregation and adhesion, and leukocyte-endothelial cell interactions. Loss of NO production by the vascular endothelium results in endothelial dysfunction. These results (Figure $4(a))$ indicate that loss of NO in the endothelium upon OxLDL assault decreases the eNOS expression. Decreased mRNA expression of eNOS is indicative of the downregulation of Akt in the OxLDL treated group, because eNOS is activated by Akt. The inactive eNOS could enhance the shear stress via loss of NO bioavailability [38]. Hence this study sought to investigate the OxLDL mediated ROS generation and its inhibition by OPC. The antioxidant effect of OPC was evaluated by the formation of MDA- an index for lipid peroxidation and intracellular ROS generation was assessed using oxidation sensitive fluorescent probes, 2'7'-dichlorofluorescin diacetate (DCFH-DA). Recent studies have demonstrated that the increased lipid peroxidation correlates with the increased expression P-Selectin, IL6, MCP-1 and LOX-1, and involved in the apoptosis of endothelial cells [39]. Figure 4(b) displays the DCFDA stained endothelial cells and monocytes, which showed increase in fluorescence upon CRP+ OxLDL induction. This result directly points out that OxLDL induces ROS, RNS and $\mathrm{H}_{2} \mathrm{O}_{2}$ generation. Thus, the increased ROS and RNS generation mediates the increased transendothelial migration by upregulation of LOX-1, MCP-1, IL-6, IL-1ß, L- selectin and TF which, in turn, activates the proinflammatory NFkB, angiogenesis and shear stress. OPC treated group showed decreased fluorescence compared to OxLDL treated group. OPC has strong antioxidative capacity, high affinity for the lipid bilayers of the cell membrane and hence, can easily enter the nuclei of cells. OPC is readily water soluble and oxidizable. Its catechol structure also makes OPC a strong chelator of metal ions. Ellagic acid, anthocyanins and punicalagins also elucidate the attenuation of ROS and thus, prevent endothelial dysfunction and atherosclerosis $[40,41]$.

The formation of capillary tube in in vitro is a significance of endothelial cell differentiation. As discussed earlier, OxLDL and CRP known to direct the loss of angiogenic properties of endothelial via activating apoptotic pathway. The ability of OxLDL to stimulate capillary tube formation in the experimental group was established in this study. As shown in Figure 5(a) \& (b), CRP+OxLDL induction led to the formation of capillary-like structures. Normal endothelial cells grow and proliferate and tend to form tubule- like structures. Endothelial cells uptake OxLDL by a well-known scavenger receptor, LOX-1. Hence, the formation of capillary tubes may be dependent on the upregulation of LOX-1 dependent mechanism [42]. The other factors for the formation of capillary-like structure are shear stress, relevant to migration and angiogenesis stimulation; and av $\beta 3$-integrin which plays a critically important role in angiogenesis stimulated by OxLDL [43]. The endothelial cells treated with OPC, showed a significant decrease in the tube forming capacity. Blueberry also inhibited angiogenesis in ECV304 cells by suppressing migration and tube formation [44]. Upon co treatment with OPC under the stimulation of OxLDL and CRP resulted in the formation of capillary tubes when compared to control group of cells significantly. 
The wound-healing assay is used to estimate the migration potential of endothelial cells in monolayer culture stimulated by OxLDL. As shown in Figure 6(a\&b), group I (control) cells showed increased migration, group II showed significantly reduced cell migration even after $72 \mathrm{~h}$, which may be due to the cytotoxic effect of CRP+OxLDL that promotes apoptosis of the endothelial cells. The OPC treated coculture model showed a dramatic increase in the migration of cells from $0 \mathrm{~h}$ to $72 \mathrm{~h}$, thus, treatment with OPC could amend the toxic effects of OxLDL and thereby promote regrowth of denuded endothelium. Anthocyanins isolated from black soybean seed coat enhance wound healing, through cytoprotective effect, enhance angiogenesis, and exert anti-inflammatory effect [45]. Chang et al., (2006) have shown that anthocyanin-rich extract of Hibiscus inhibited LDL oxidation and OxLDL-mediated macrophage apoptosis [46].

mRNA analysis of experimental cells as shown in figure (7(a-d)) shows down regulation of proinflammatory molecules MCP- 1 and IL- 6 and membrane scavenger receptor LOX-1 levels when treated with OPC, whereas increased expression proinflammatory molecules supports the accumulation of ROS, increased adhesion of monocytes, increased expression of endothelial scavenger receptor LOX-1. LSelectin is a type I, membrane cell adhesion molecules that is expressed on the surface of most circulating leukocytes. The function of L-selectin on the leukocytes to leave the bloodstream, make random contacts and tether to activate endothelial cell layer allows leukocytes to encounter their target antigen in inflamed tissues. Endothelial ligands of L-Selectin are GlyCAM-1, CD34, Sgp200 and PCLP, which enhances L-selectin expression on the monocytes supports tethering and rolling along vascular endothelium.

Abnormal transendothelial migration of monocytes initiated by accumulation of OxLDL in the subendothelial layer of the blood vessels is a well-known factor, which elicits atherosclerosis [47]. This transmigratory process involves several steps including slow rolling, adhesion strengthening, crawling, paracellular and transcellular migration and transmigration through the basement membrane, which is mediated by Monocyte Chemoattractant Protein-1 (MCP-1), a chemokine that plays an important role in monocyte trafficking across the endothelial layer [48]. Previous studies have clearly shown that MCP-1 plays a pivotal role in the monocyte migration and its further differentiation into macrophages under the induction of OxLDL [49]. The mRNA expression of MCP-1 was found to be elevated in the OxLDL treated coculture, when compared to Group 1. This could be because of OxLDL is known to elicit the chemokine MCP-1, further responsible for the increased transmigration of monocytes, endothelial dysfunction and activation. This is in agreement with other studies, that the migration of leukocytes towards the site of inflammation is highly dependent on chemotactic effects of MCP-1. As suggested by other researchers, upregulation of MCP-1 by OxLDL, further activates LOX-1 [50], IL-6 [51] and TF [53] expression on the endothelial cells, which directly influences the endothelial dysfunction. MCP-1 levels were found to be significantly reduced in the OPC treated group, due to their antioxidant activity. Numerous lines of evidence have favored the antioxidant activity of phytomedicine in suppressing the levels of MCP-1. Ginkgo biloba extract attenuated OxLDL-induced oxidative functional damage in endothelial cells [ ]. Another study by Ou et al. (2010) showed that EGCG also protects the OxLDL induced endothelial dysfunction via inhibiting LOX-1 mediated signaling [55]. 6-shogaol prevents the OxLDL-induced LOX-1- 
mediated biological events in HUVECs, probably via its antioxidative and anti-inflammatory functions [56]. Resveratrol inhibits the effects of Nox1 and MCP-1 expression via Akt and FoxO3 signaling pathways [57]. Thus, treatment with OPC attenuates the MCP-1 levels and thereby limits the transendothelial monocyte migration associated with inflammation.

Studies have shown that induction of LOX-1 expression is stimulated by many factors, such as inflammatory cytokines, oxidative stress, hemodynamic stimuli and OxLDL [58]. LOX-1 is considered as the key atherogenic factor; because under normal conditions, the expression of LOX-1 is rarely detected, whereas, upon proinflammatory and proatherogenic stimuli, LOX-1 is upregulated [59]. Recent evidences have demonstrated that LOX-1 activation induces oxidative stress which, in turn, stimulates more LOX-1 expression, suggesting a direct relationship between oxidative stress and LOX-1 expression [60]. When treated with OPC there was marked decrease in the LOX-1 expression. This suppression of LOX-1, may be due to antioxidant and anti-inflammatory properties of OPC, which is, supported by other investigations on the anti-atherogenic effects of ellagic acid, EGCG, anthocyanins, 4-0xo-Flavonoids and procyanidins, that exert their protective effects by inhibiting ROS generation, thus, attenuating CRP+OxLDL induced LOX-1 upregulation in endothelial cells [62].

Monocyte adhesion onto the endothelial cells further stimulates the secretion of IL- 6 involved mainly in inflammation and eventual progression to atherosclerosis [63]. This study also showed increased expression of IL- 6 in the CRP+OxLDL induced group, when compared to control group. Previous studies have stated that the OxLDL induces IL-6, CRP and MCP-1 suggesting an inflammatory process and its association with calcification. OPC showed reduced CRP+OxLDL induced IL-6 mRNA expression, when compared to $\mathrm{CPR}+\mathrm{OxLDL}$ induced group. From previous study, supplementation of anthocyanins had been demonstrated to modulate the expression of both IL-6 and VCAM-1. Feeding anthocyanin rich bilberry and strawberry beverages to human participants with elevated risk of CVD reported reduced plasma concentrations of IL-6 and C-reactive protein [64]. The effect of Cyanidins 3 Glycoside metabolites on OxLDL induced IL-6 production in vitro suggests its anti-inflammatory effect [65].

ROS leads to disruption of mitochondrial membrane potential $(\Delta \psi)$, in general this process is considered as an early step toward cell death. The FACS analysis of JC- 1 dye in control and experimental groups (Figure 8(a)). These results suggested that $\mathrm{JC}-1$ aggregates were seen in cells treated with OPC, whereas JC-1 monomers were seen in cells treated with CRP+OxLDL. The ability of OxLDL to stimulate entry of cells into cell cycle arrest was analysed by flow cytometry. The anti-apoptotic effect of OPC on endothelial cells was evaluated in two separate sets of experiments, one with co-culture and the other just the endothelial cells alone. The co-culture model was analysed for cell cycle arrest upon OxLDL stimulation. Figure: 8(b) showed a substantial decrease in the proportion of cells in G0/G1 phase and increased cell death. Therefore, OxLDL induction demonstrates cell cycle arrest and inhibition of growth. Surprisingly, OPC treated group also showed G0/G1 arrest and showed increased cell death as compared to OxLDL treated group, while in all other experiments of this study, OPC had shown promising cytoprotective effect. This vividly different result was observed only for the co-culture induced with $\mathrm{CRP}+\mathrm{OxLDL}$ and treated with OPC. 
The possible intervention of OPC against CRP+ OXLDL was summarized in figure (9). Therefore, from the above results and discussion, this study strongly supports the anti-oxidant, anti-angiogenic and antiinflammatory effects of OPC against CRP+OxLDL induced endothelial dysfunction. Hence, OPC could be able intervene the inflammatory phase triggered upon CRP and OXLDL induction and thereby OPC may be potent cardioprotective agent.

\section{Declarations}

Authors contribution: SJ, AKR and SND: Study conception, experimental design, analysis and interpretation of data. SJ and AKR : drafting the article and SND revising and final approval of the manuscript. All authors read and approved the final manuscript.

Funding: Authors would like to acknowledge the University Grants Commission (UGC), New Delhi, India, for financial support under UGC-BSR meritorious fellowship.

Competing interests: All authors declare that they have no competing interests.

Availability of data and material: Yes. Data and results have been generated as part of my doctoral thesis work.

Ethics approval: Not applicable

Consent to publish: Not applicable

Consent for publication: Not applicable.

\section{References}

1. Manduteanu, I., \& Simionescu, M. (2012). Inflammation in atherosclerosis: a cause or a result of vascular disorders?. Journal of cellular and molecular medicine, 16(9), 1978-1990.

2. Raggi, Paolo, et al. "Role of inflammation in the pathogenesis of atherosclerosis and therapeutic interventions." Atherosclerosis 276 (2018): 98-108.

3. Badimon, L., Peña, E., Arderiu, G., Padró, T., Slevin, M., Vilahur, G., \& Chiva-Blanch, G. (2018). Creactive protein in atherothrombosis and angiogenesis. Frontiers in immunology, 9, 430.

4. Sproston, N. R., \& Ashworth, J. J. (2018). Role of C-reactive protein at sites of inflammation and infection. Frontiers in immunology, 9, 754.

5. Granger, D.N., Senchenkova, E. (2010). Inflammation and the Microcirculation. San Rafael (CA): Morgan \& Claypool Life Sciences; Chapter 7, Leukocyte-Endothelial Cell Adhesion.

6. Kany, S., Vollrath, J. T., \& Relja, B. (2019). Cytokines in inflammatory disease. International journal of molecular sciences, 20(23), 6008. 
7. Harmon, M. E., Campen, M. J., Miller, C., Shuey, C., Cajero, M., Lucas, S., ... \& Lewis, J. (2016). Associations of circulating oxidized LDL and conventional biomarkers of cardiovascular disease in a cross-sectional study of the Navajo population. PloS one, 11(3), e0143102.

8. Wang, J., Feng, M. J., Zhang, R., Yu, D. M., Zhou, S. J., Chen, R., \& Yu, P. (2016). C-reactive protein/oxidized low density lipoprotein/ $\beta 2$-glycoprotein i complexes induce lipid accumulation and inflammatory reaction in macrophages via p38/mitogen-activated protein kinase and nuclear factor-KB signaling pathways. Molecular medicine reports, 14(4), 3490-3498.

9. Yasojima, K., Schwab, C., McGeer, E. G., \& McGeer, P. L. (2001). Generation of C-reactive protein and complement components in atherosclerotic plaques. The American journal of pathology, 158(3), 1039-1051.

10. Singh, U., Dasu, M. R., Yancey, P. G., Afify, A., Devaraj, S., \& Jialal, I. (2008). Human C-reactive protein promotes oxidized low density lipoprotein uptake and matrix metalloproteinase-9 release in Wistar rats. Journal of Lipid Research,49(5), 1015-1023.

11. Rajendran, Shanthi, et al. "Effect of tincture of Crataegus on the LDL-receptor activity of hepatic plasma membrane of rats fed an atherogenic diet." Atherosclerosis 123.1-2 (1996): 235-241.

12. Rajalakshmi, K., Prema Gurumurthi, and S. Niranjali Devaraj. "Effect of eugenol and tincture of crataegus (TCR) on in vitro oxidation of LDL+ VLDL isolated from plasma of non-insulin dependent diabetic patients." (2000).

13. Thirupurasundari, C. J., R. Jayalakshmi, and S. Niranjali Devaraj. "Liver architecture maintenance by tincture of Crataegus against isoproterenol-induced myocardially infarcted rats." Journal of medicinal food 8.3 (2005): 400-404.

14. Elango, Chinnasamy, and Sivasithambaram Niranjali Devaraj. "Immunomodulatory effect of Hawthorn extract in an experimental stroke model." Journal of neuroinflammation 7.1 (2010): 1-13.

15. Thiruchenduran, M., Vijayan, N. A., Sawaminathan, J. K., \& Devaraj, S. N. (2011). Protective effect of grape seed proanthocyanidins against cholesterol cholic acid diet-induced hypercholesterolemia in rats. Cardiovascular Pathology, 20(6), 361-368.

16. Thiruchenduran Mohana, Alukkathara Vijayan Navin, Sankar Jamuna, Mohammed Sadullah Sakeena Sadullah, Sivasithamparam Niranjali Devaraj, (2015). Inhibition of differentiation of monocyte to macrophages in atherosclerosis by oligomeric proanthocyanidins - in-vivo and in-vitro study. Food and Chemical Toxicology. 82 (2015) 96-105.

17. Ashokkumar Rathinavel, Sankar Jamuna, Sakeena Sadullah Mohammed Sadullah, Sivasitambaram Niranjali Devaraj Oligomeric proanthocyanidins protect myocardium by mitigating left ventricular remodeling in Isoproterenol induced Post-myocardial infarction. Fundamental and clinical pharmacology.32, (1),51-59.

18. Sankar J, Rathinavel A, Sakeena Sadullah MS, Devaraj SN. Oligomeric proanthocyanidins mitigate cholesterol and cholic acid diet-induced hepatic dysfunction in male Sprague Dawley rats. J Biochem Mol Toxicol. 2018; e22234. 
19. Sankar Jamuna, Ashokkumar Rathinavel, Sakeena Sadullah Mohammed Sadullah, and Sivasitamparam Niranjali Devaraj. Oligomeric proanthocyanidins and Epigallocatechin gallate aggravate autophagy of foam cells through the activation of Class III PI3K/Beclin1-complex mediated cholesterol efflux. Biofactors, 2019;45(5):763-77.

20. Binkowski, T. A., Naghibzadeh, S., \& Liang, J. (2003). CASTp: computed atlas of surface topography of proteins. Nucleic acids research, 31(13), 3352-3355.

21. Werner, J., Geldenhuys, Kevin, E., Gaasch, Mark Watson, David, D. (2006). Allen and Cornelis J. Vander Schyf, Optimizing the use of opensource software applications in drug discovery, Drug Discovery Today, 11(3-4)127-132.

22. Duhovny, D., Nussinov, R., Wolfson, H.J., (2002). Efficient Unbound Docking of Rigid Molecules. In Gusfield et al., Ed. Proceedings of the 2'nd Workshop on Algorithms in Bioinformatics(WABI) Rome, Italy, Lecture Notes in Computer Science 2452, pp. 185-200, Springer Verlag, 2002.

23. Schneidman-Duhovny, D., Inbar, Y., Nussinov, R., \& Wolfson, H. J. (2005). PatchDock and SymmDock: servers for rigid and symmetric docking. Nucleic acids research, 33(suppl_2), W363-W367.

24. Jamuna, S., Sadullah, S., Ashokkumar, R., Shanmuganathan, G., \& Mozhi, S. S. (2017). Potential antioxidant and cytoprotective effects of essential oil extracted from Cymbopogon citratus on OxLDL and H2O2 LDL induced Human Peripheral Blood Mononuclear Cells (PBMC). Food Science and Human Wellness, 6(2), 60-69.

25. Kumar, P., Pai, K., Pandey, H.P., Sundar, S. (2002). NADH-oxidase, NADPH-oxidase and myeloperoxidase activity of visceral leishmaniasis patients. J. Med. Microbiol. $\quad$ 51(10):832-836.

26. Schulz, K., Kerber, S., \& Kelm, M. (1999). Reevaluation of the Griess method for determining NO/NO2 in aqueous and protein-containing samples. Nitric oxide, 3(3), 225-234.

27. Zhang, C., Yang, F., Zhang, X.W., Wang, S.C., Li, M.H., Lin, L.P., Ding, J. (2006). Grateloupia longifolia polysaccharide inhibits angiogenesis by downregulating tissue factor expression in HMEC-1 endothelial cells. Br. J..Pharmacol.148:741-751.

28. Talapatra, S. N., Talukdar, P., \& Swarnakar, S. (2017). Interaction between C-reactive protein and Phytochemical (s) from Calotropis procera: An Approach on Molecular Docking. International Letters of Natural Sciences, 61, 43-55.

29. Shakour, N., Ruscica, M., Hadizadeh, F., Cirtori, C., Banach, M., Jamialahmadi, T., \& Sahebkar, A. (2020). Statins and C-reactive protein: in silico evidence on direct interaction. Archives of Medical Science: AMS, 16(6), 1432.

30. Shakour, Neda, et al. "Curcumin Can Bind and Interact with CRP: An in silico Study." Pharmacological Properties of Plant-Derived Natural Products and Implications for Human Health 1308 (2021): 91100.

31. Baldus, S., Eiserich, J. P., Mani, A., Castro, L., Figueroa, M., Chumley, P., ... \& Freeman, B. A. (2001). Endothelial transcytosis of myeloperoxidase confers specificity to vascular ECM proteins as targets of tyrosine nitration. The Journal of clinical investigation, 108(12), 1759-1770. 
32. Csató, V., Pető, A., Fülöp, G. Á., Rutkai, I., Pásztor, E. T., Fagyas, M., ... \& Papp, Z. (2015).

Myeloperoxidase evokes substantial vasomotor responses in isolated skeletal muscle arterioles of the rat. Acta Physiologica, 214(1), 109-123.

33. Panés, J., Perry, M., \& Granger, D. N. (1999). Leukocyte-endothelial cell adhesion: avenues for therapeutic intervention. British journal of pharmacology, 126(3), 537-550.

34. Gu, B., Dao, L. P., \& Wiley, J. (2001). Impaired transendothelial migration of B-CLL lymphocytes: a defect linked to low L-selectin expression. Leukemia \& lymphoma, 42(1-2), 5-12.

35. Strell. C., \& Entschladen. F., (2008). Extravasation of leukocytes in comparison to tumor cells. Cell Communication and Signaling: CCS. 6:10.

36. Hajjar, D. P., \& Gotto Jr, A. M. (2013). Biological relevance of inflammation and oxidative stress in the pathogenesis of arterial diseases. The American journal of pathology, 182(5), 1474-1481.

37. Forte, M., Conti, V., Damato, A., Ambrosio, M., Puca, A. A., Sciarretta, S., ... \& Carrizzo, A. (2016). Targeting nitric oxide with natural derived compounds as a therapeutic strategy in vascular diseases. Oxidative medicine and cellular longevity, 2016.

38. Jin, X., Yi, L., Chen, M. L., Chen, C. Y., Chang, H., Zhang, T., ... \& Mi, M. T. (2013). Delphinidin-3glucoside protects against oxidized low-density lipoprotein-induced mitochondrial dysfunction in vascular endothelial cells via the sodium-dependent glucose transporter SGLT1. PLoS One, 8(7), e68617.

39. Hamoud, S., Hayek, T., Volkova, N., Attias, J., Moscoviz, D., Rosenblat, M., \& Aviram, M. (2014). Pomegranate extract (POMx) decreases the atherogenicity of serum and of human monocyte-derived macrophages (HMDM) in simvastatin-treated hypercholesterolemic patients: a double-blinded, placebo-controlled, randomized, prospective pilot study. Atherosclerosis, 232(1), 204-210.

40. Dandapat, A., Hu, C., Sun, L., \& Mehta, J. L. (2007). Small concentrations of oxLDL induce capillary tube formation from endothelial cells via LOX-1-dependent redox-sensitive pathway. Arteriosclerosis, thrombosis, and vascular biology, 27(11), 2435-2442.

41. Scazzocchio, B., Varì, R., Filesi, C., D’Archivio, M., Santangelo, C., Giovannini, C., ... \& Masella, R. (2011). Cyanidin-3-0- $\beta$-glucoside and protocatechuic acid exert insulin-like effects by upregulating PPARy activity in human omental adipocytes. Diabetes, 60(9), 2234-2244.

42. Baba, A. B., Kowshik, J., Krishnaraj, J., Sophia, J., Dixit, M., \& Nagini, S. (2016). Blueberry inhibits invasion and angiogenesis in 7, 12-dimethylbenz [a] anthracene (DMBA)-induced oral squamous cell carcinogenesis in hamsters via suppression of TGF- $\beta$ and NF-KB signaling pathways. The Journal of nutritional biochemistry, 35, 37-47.

43. Xu, L., Choi, T. H., Kim, S., Kim, S. H., Chang, H. W., Choe, M., ... \& Zhang, D. (2013). Anthocyanins from black soybean seed coat enhance wound healing. Annals of Plastic Surgery, 71(4), 415-420.

44. Chang, Y. C., Huang, K. X., Huang, A. C., Ho, Y. C., \& Wang, C. J. (2006). Hibiscus anthocyanins-rich extract inhibited LDL oxidation and oxLDL-mediated macrophages apoptosis. Food and Chemical Toxicology, 44(7), 1015-1023. 
45. Schnoor, M., Alcaide, P., Voisin, M. B., \& van Buul, J. D. (2015). Crossing the vascular wall: common and unique mechanisms exploited by different leukocyte subsets during extravasation. Mediators of inflammation, 2015.

46. Yao, Y., \& Tsirka, S. E. (2014). Monocyte chemoattractant protein-1 and the blood-brain barrier. Cellular and molecular life sciences, 71(4), 683-697.

47. Seo, J. W., Yang, E. J., Yoo, K. H., \& Choi, I. H. (2015). Macrophage differentiation from monocytes is influenced by the lipid oxidation degree of low density lipoprotein. Mediators of inflammation, 2015.

48. Mattaliano, M. D., Huard, C., Cao, W., Hill, A. A., Zhong, W., Martinez, R. V., ... \& Shih, H. H. (2009). LOX1-dependent transcriptional regulation in response to oxidized LDL treatment of human aortic endothelial cells. American Journal of Physiology-Cell Physiology, 296(6), C1329-C1337.

49. Hashizume, M., \& Mihara, M. (2012). Blockade of IL-6 and TNF-a inhibited oxLDL-induced production of MCP-1 via scavenger receptor induction. European journal of pharmacology, 689(1-3), 249-254.

50. Bode, M., \& Mackman, N. (2014). Regulation of tissue factor gene expression in monocytes and endothelial cells: thromboxane A2 as a new player. Vascular pharmacology, 62(2), 57-62.

51. Ou, H. C., Chou, F. P., Sheen, H. M., Lin, T. M., Yang, C. H., \& Sheu, W. H. H. (2006). Resveratrol, a polyphenolic compound in red wine, protects against oxidized LDL-induced cytotoxicity in endothelial cells. Clinica Chimica Acta, 364(1-2), 196-204.

52. Hong, Y. J., Huang, X. M., Liu, X. B., Zhang, C. Y., Zhang, L., \& Xu, X. L. (2013). 6-Shogaol protects against oxidized LDL-induced endothelial injruries by inhibiting oxidized LDL-evoked LOX-1 signaling. Evidence-Based Complementary and Alternative Medicine, 2013.

53. Park, K. H., \& Park, W. J. (2015). Endothelial dysfunction: clinical implications in cardiovascular disease and therapeutic approaches. Journal of Korean medical science, 30(9), 1213-1225.

54. Lubrano, V., \& Balzan, S. (2014). LOX-1 and ROS, inseparable factors in the process of endothelial damage. Free Radical Research, 48(8), 841-848.

55. Ghazi-Khanloosani, M., Bandegi, A. R., Kokhaei, P., Barati, M., \& Pakdel, A. (2019). CRP and LOX-1: a mechanism for increasing the tumorigenic potential of colorectal cancer carcinoma cell line. Pathology \& Oncology Research, 25(4), 1467-1475.

56. Zuniga, F. A., Ormazabal, V., Gutierrez, N., Aguilera, V., Radojkovic, C., Veas, C., ... \& Aguayo, C. (2014). Role of lectin-like oxidized low density lipoprotein-1 in fetoplacental vascular dysfunction in preeclampsia. BioMed research international, 2014.

57. E. Wetter Au, A, S.-S. Stecher, B.Wolff1,B, S. Khouri,A. Staudt,C, S.B. Felix1, M. Landsberger (2013). Human Endotheliallecitin-Like Oxldlreceptor-1 (Lox-1) Expression Is Notassociated With Impairmentof Endothelium-Dependent Vasoreactivityin Conduitvessels. Journalof Physiologyand Pharmacology, 64, 4, 465-472.

58. Amin, H. P., Czank, C., Raheem, S., Zhang, Q., Botting, N. P., Cassidy, A., \& Kay, C. D. (2015). Anthocyanins and their physiologically relevant metabolites alter the expression of IL- 6 and VCAM-1 in CD40L and oxidized LDL challenged vascular endothelial cells. Molecular nutrition \& food research, 59(6), 1095-1106. 
59. Scheller, J., Chalaris, A., Schmidt-Arras, D., \& Rose-John, S. (2011). The pro-and anti-inflammatory properties of the cytokine interleukin-6. Biochimica et Biophysica Acta (BBA)-Molecular Cell Research, 1813(5), 878-888.

60. Wallace, T. C. (2011). Anthocyanins in cardiovascular disease. Advances in nutrition, 2(1), 1-7.

61. Amin, H., Czank, C., Cassidy, A., \& Kay, C. D. (2012). Effect of cyanidin-glucoside and its metabolites on inflammatory biomarkers of vascular function. Proceedings of the Nutrition Society, 71(OCE2). 62. http://accelrys.com/.

\section{Figures}


(a) 3D structure of CRP (PDB.ID: 1GNH)

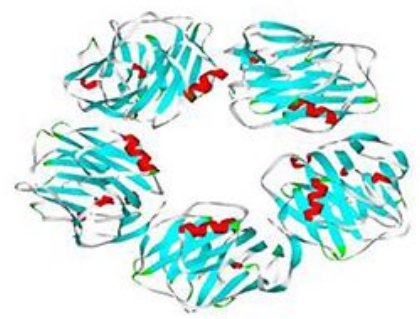

(c) Active site of CRP

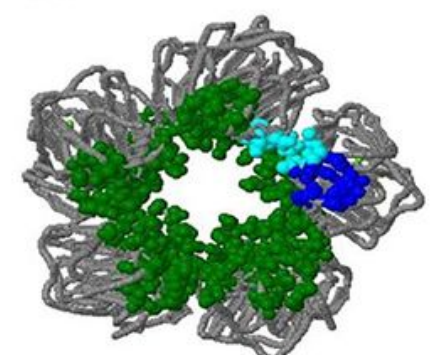

(e) Protein-protein Interaction CRP- LOX complex
Cotein-protein interact

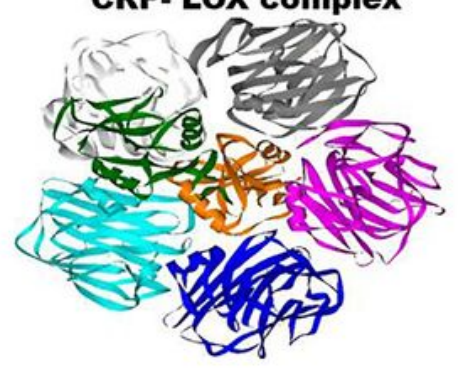

(b) 3D structure of LOX-1

(PDB.ID: 1YXK)

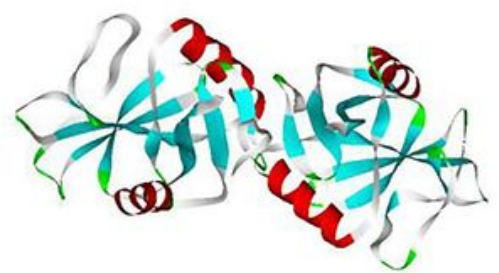

(d) Active site of LOX-1

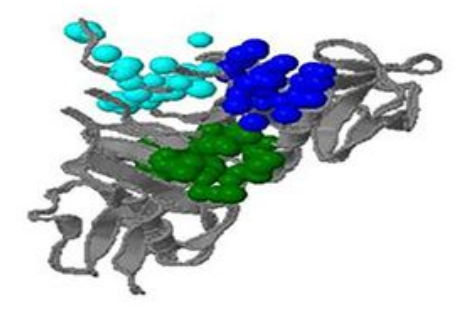

(f) Protein-Ligand Interaction CRP- OPC complex

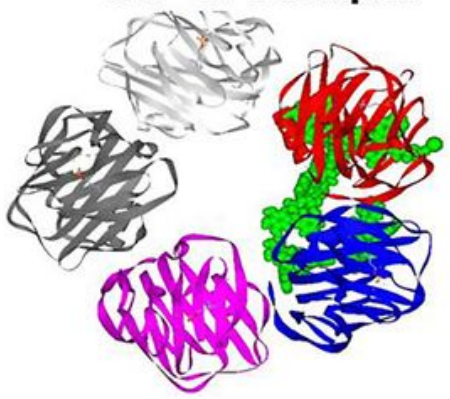

(g) Interactome of CRP- LOX- OPC complex

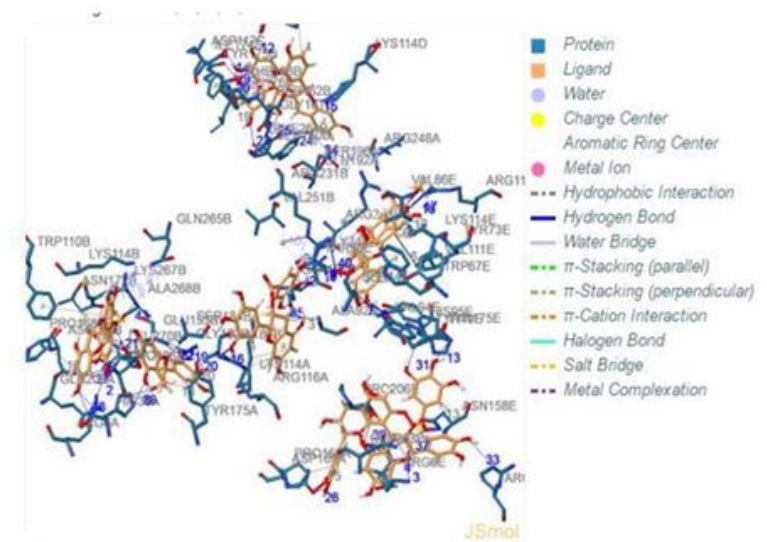

Figure 1

(a) 3D structure of CRP (PDB ID: 1GNH), (b) 3D structure of LOX-1 (PDB.ID: 1YXK), (c) Active prediction of CRP, (d) Active prediction of LOX-1, (e) Protein-Protein interaction of CRP+LOX1; (f) Molecular docking of CRP+LOX1 + OPC and (f) Interactome of CRP- LOX- OPC complex . 
(a) MTT assay for coculture model (ECV304 cells +THP-1 cells induced with CRP)

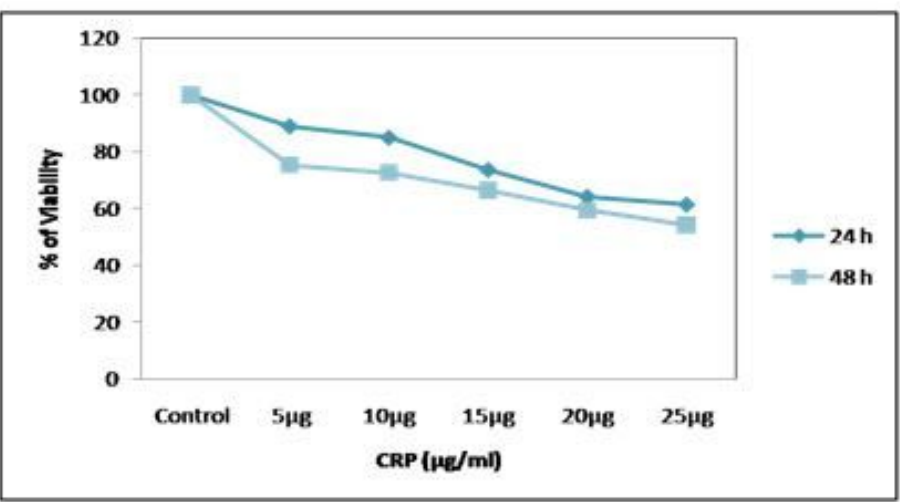

(b) MTT assay for coculture model (ECV304 cells +THP-1 cells induced with OxLDL)

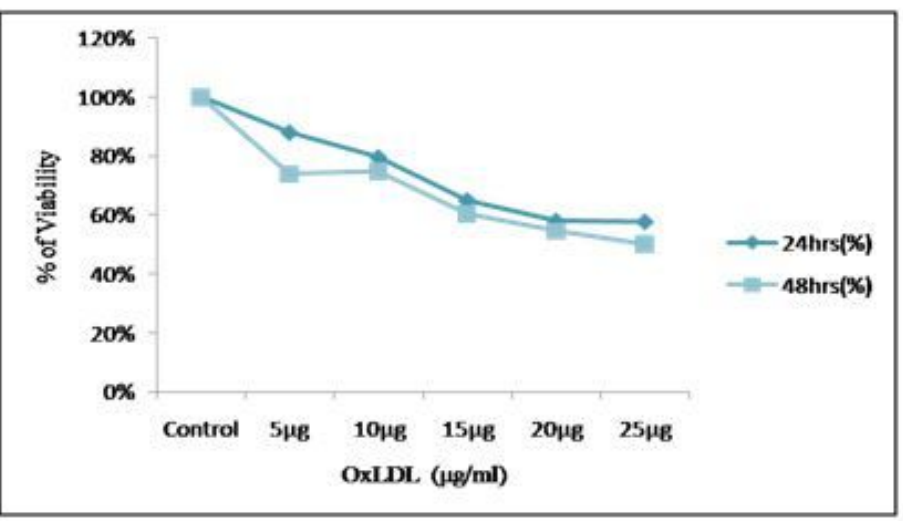

(c) MTT assay for coculture model (ECV304 cells +THP-1 cells induced with OxLDL)

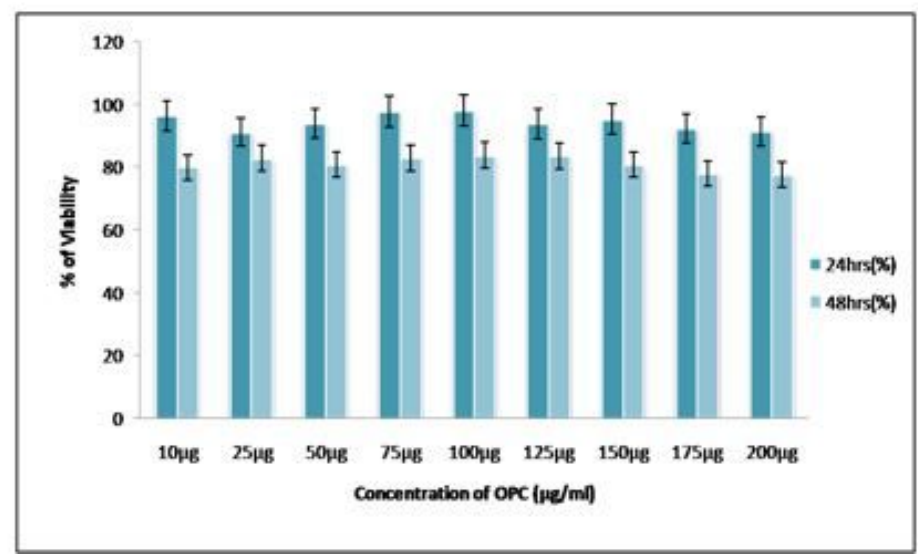

Figure 2

Study of Cytotoxic effect of (a) CRP , (b) OxLDL and (c) OPC on coculture model (ECV $304+$ THP 1 cells) by MTT assay. All values are expressed as the mean \pm SD of triplicates. 


\section{(a) Quantification of myleoperoxidase}

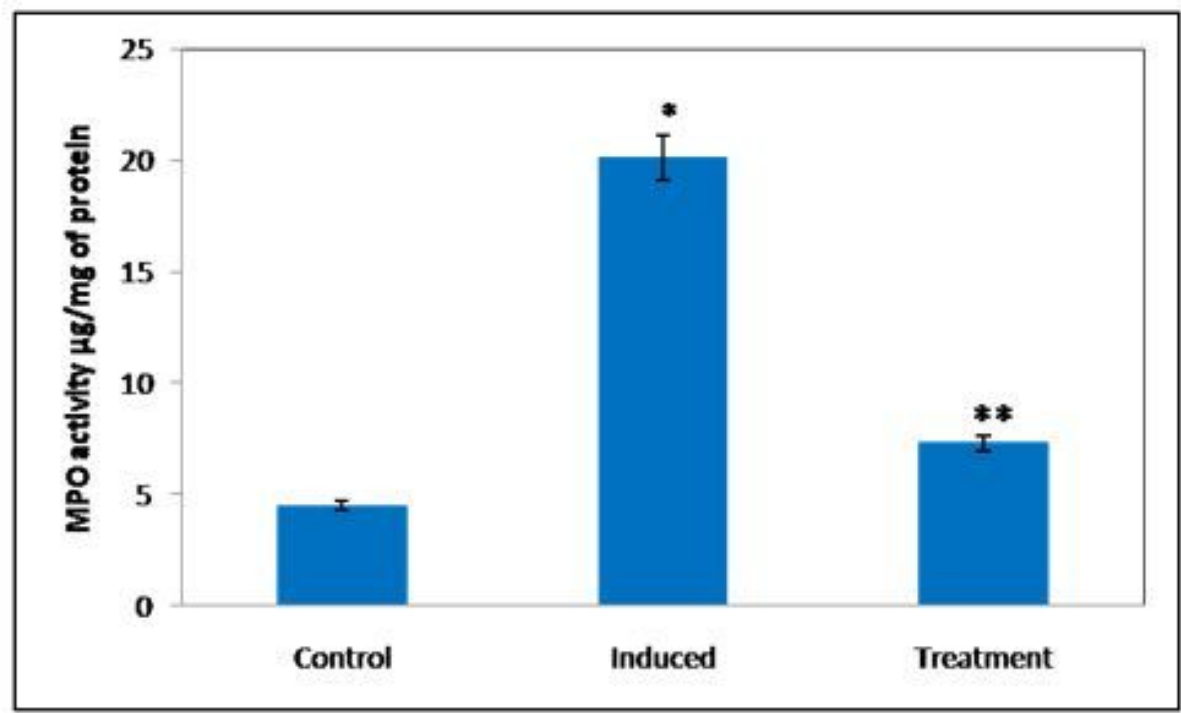

\section{(b) mRNA expression of L-Selectin}
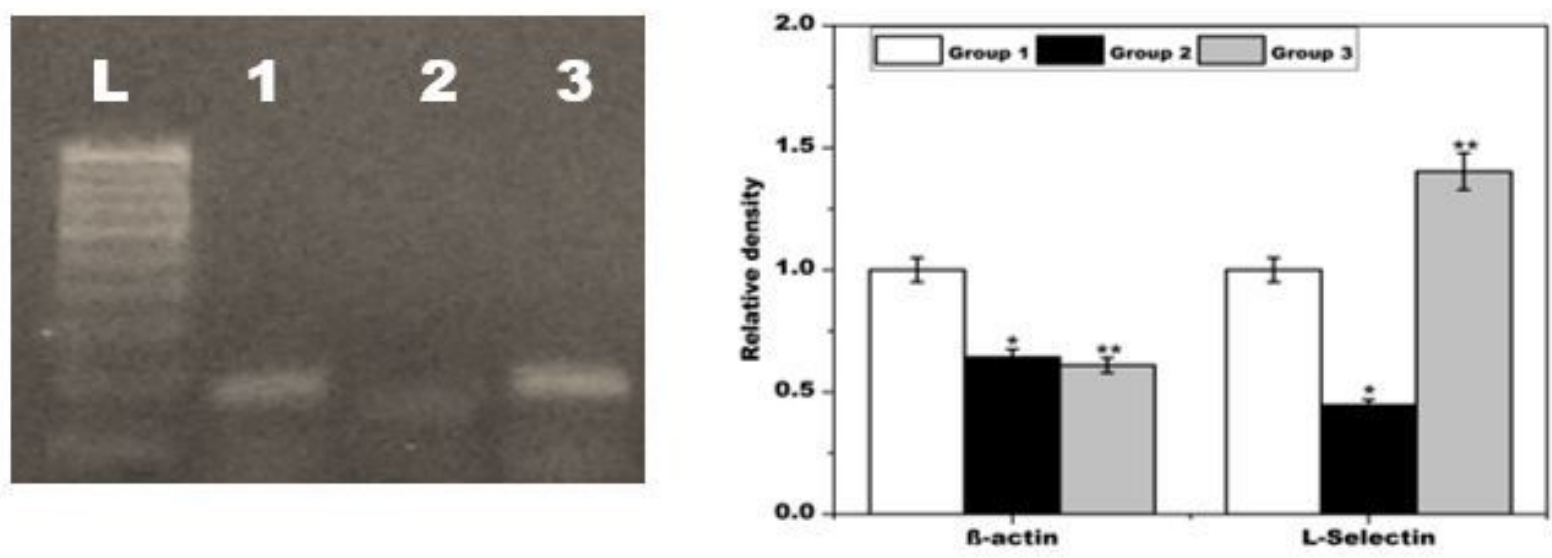

\section{L- DNA ladder (100-1000 kb); 1- Group I ; 2- Group II : 3- Group III}

${ }^{*} p<0.05,{ }^{*} \mathrm{CRP}+\mathrm{OxLDL}\left({ }^{*}\right)$ compared with control. OPC treated $(* *)$ were compared with induced group.

Figure 3

Assessment of adhesion of monocytes onto endothelial cells upon CRP+OXLDL induction in control and experimental groups. (a) Quantification of myleoperoxidase (b) mRNA expression of L-selectin. All values are expressed as the mean \pm SD of triplicates. 


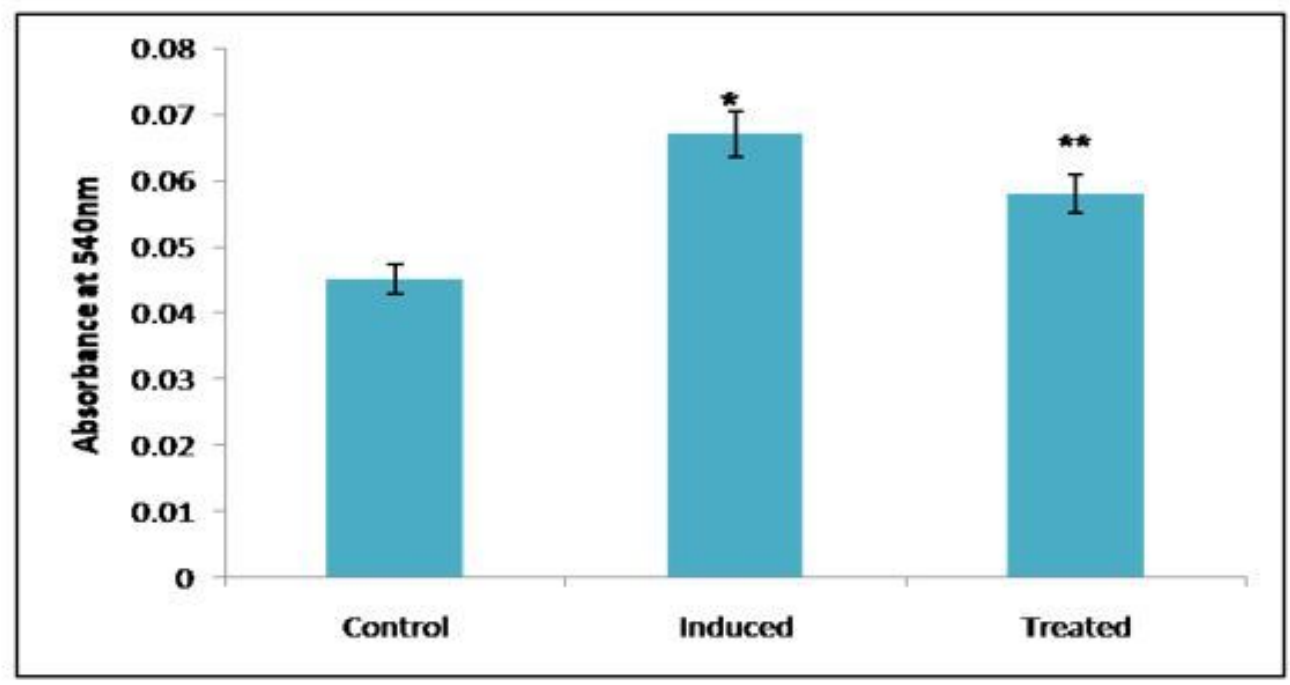

\section{Figure 4 (b) DCF-DA staining}

Group 1

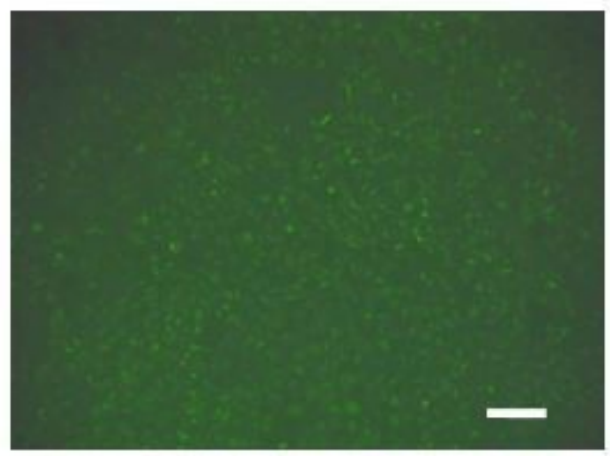

Group 3
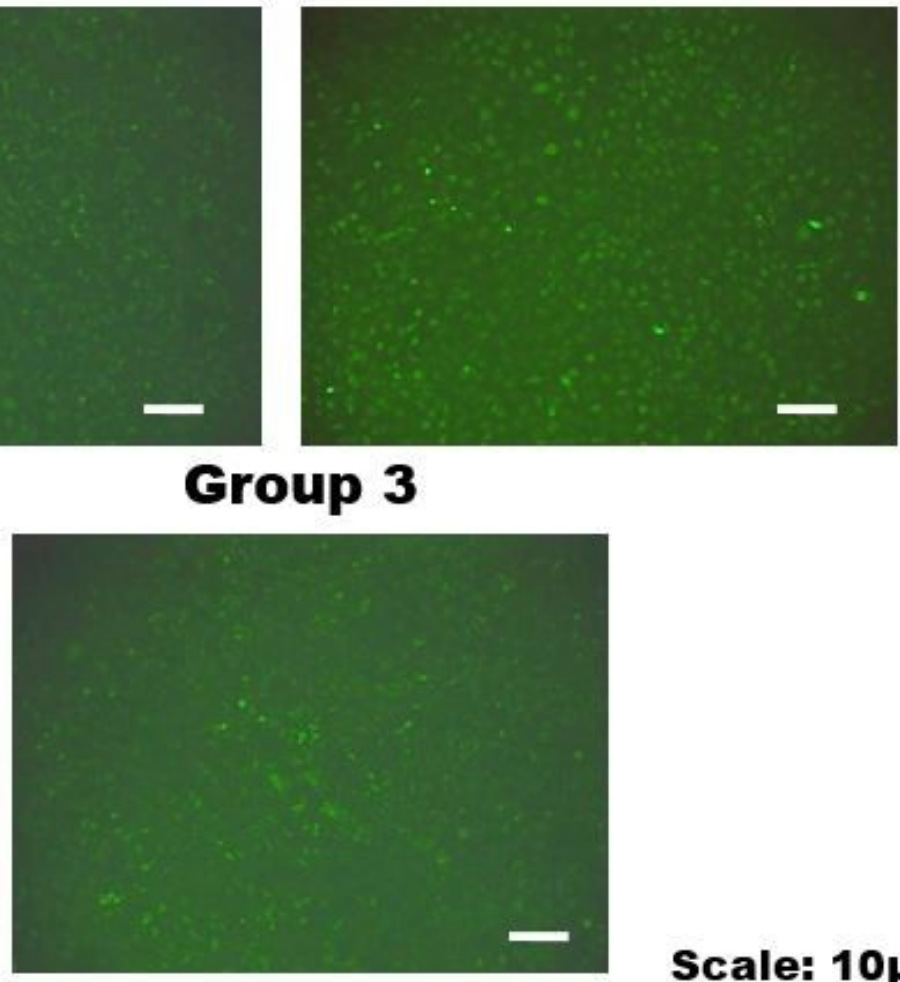

Group 2

\section{Scale: $10 \mu \mathrm{m}$}

${ }^{*} p<0.05,{ }^{*} \mathrm{CRP}+\mathrm{OxLDL}\left({ }^{*}\right)$ compared with control.

OPC treated $\left(^{* *}\right)$ were compared with induced group.

Figure 4

ROS generation upon CRP+ OxLDL induction was assessed using (a) Griess assay of control and experimental groupings. All values are expressed as the mean \pm SD of triplicates and (b) DCF DA fluorescence staining of Coculture model cells. Scale: $10 \mu \mathrm{m}$. 
Group 1

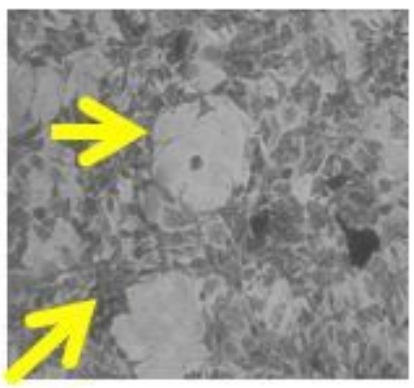

Group II

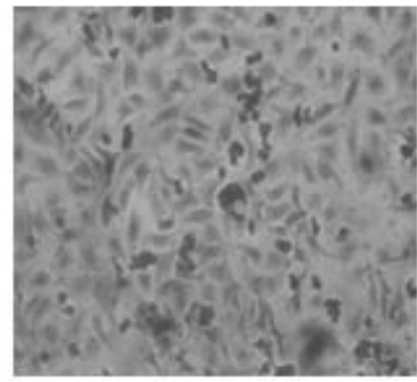

Group III

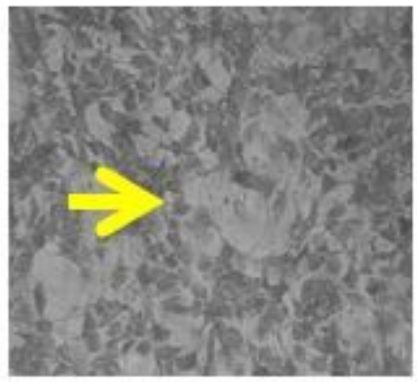

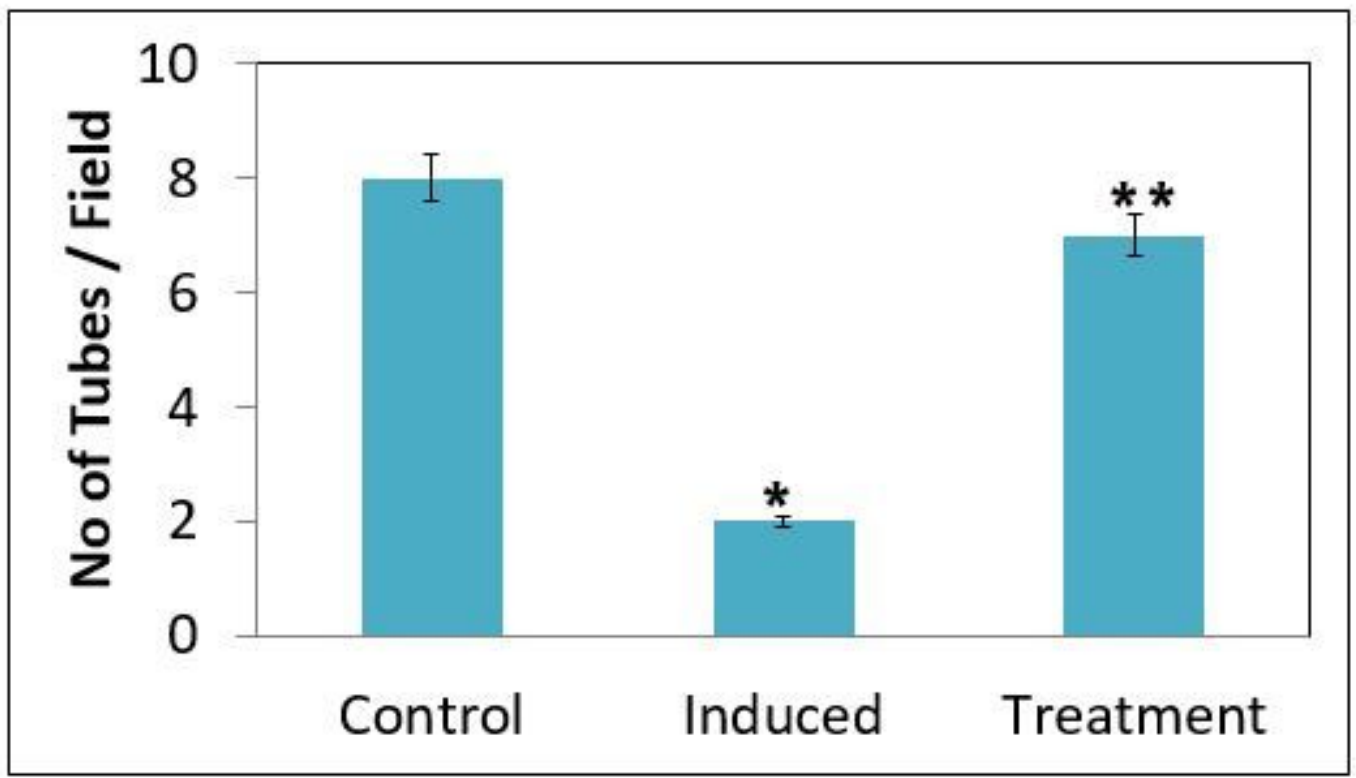

\section{${ }^{*} p<0.05, *$ CRP+OxLDL $(*)$ compared with control. OPC treated $(* *)$ were compared with induced group.}

Figure 5

(a) Microscopic images of Capillary tube formation assay of control and experimental groupings. Yellow color arrow represents the network formation. Scale: 10 $\mu \mathrm{m}$ (b) Graphical representations of tube formation counted per field. All values are expressed as the mean \pm SD of triplicates. 

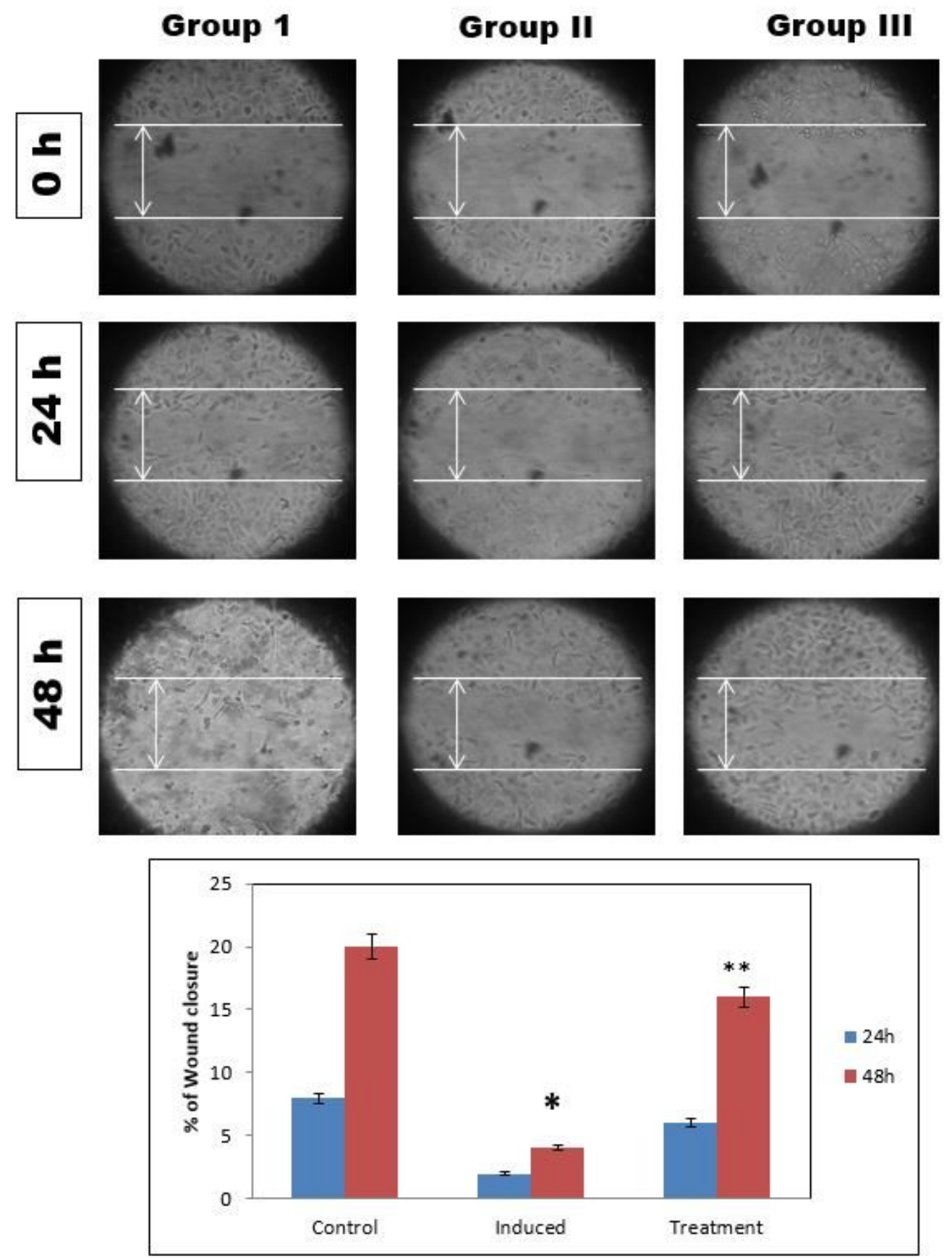

\section{* $p<0.05$, * CRP+OxLDL $(*)$ compared with control. OPC treated $(* *)$ were compared with induced group.}

Figure 6

Assessment of wound healing effects OPC against CRP+ OxLDL induction. Microscopic images of scratch wound assay of control and experimental groupings. Scale: 10 $\mu \mathrm{m}$ (b) Graphical representations of migrated cells measured as $\mathrm{mm}$. All values are expressed as the mean $\pm \mathrm{SD}$ of triplicates. 

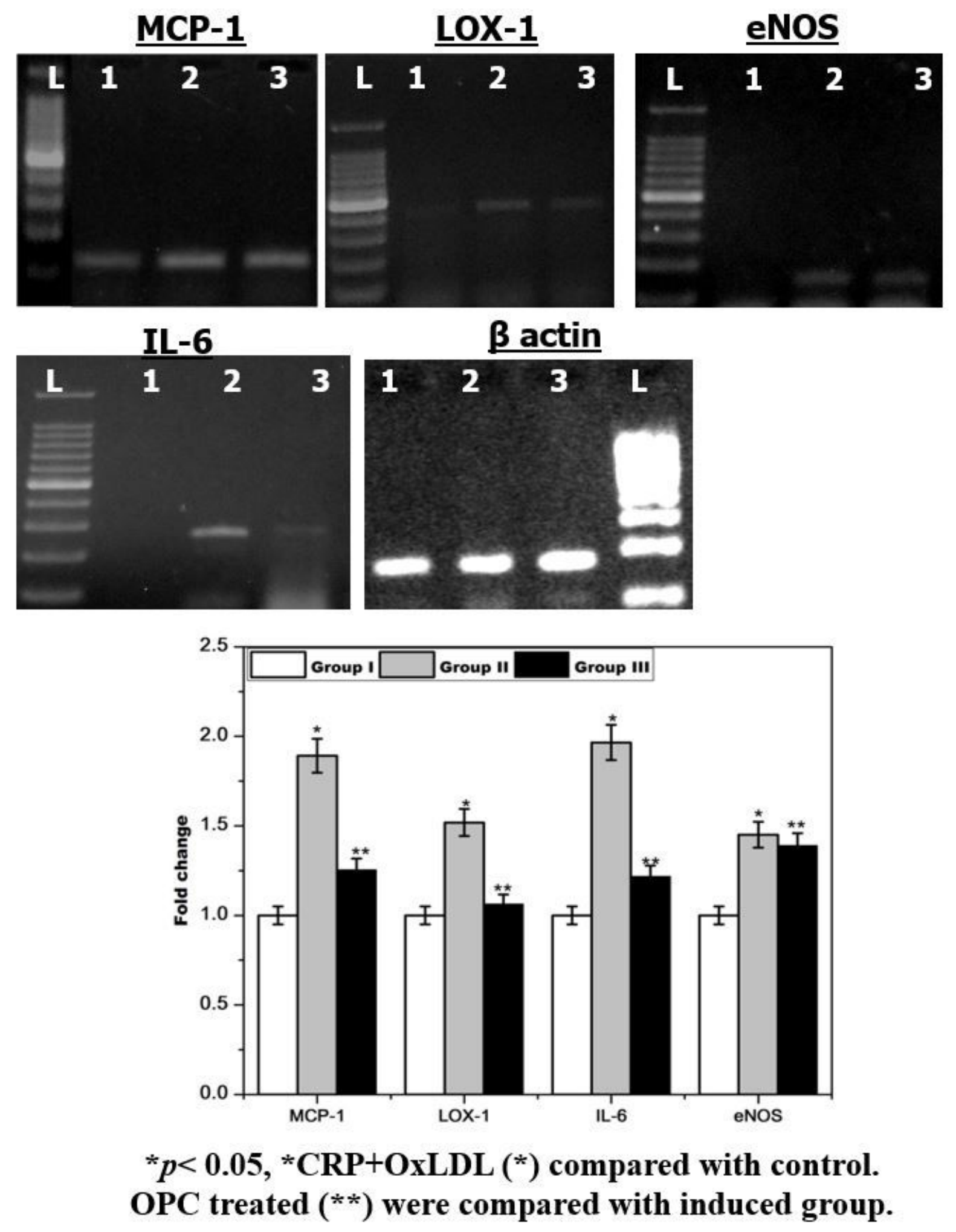

Figure 7

Analysis of mRNA Expression of key genes involved during CRP- LOX complex and regulation upon OPC treatment. All values are expressed as the mean \pm SD of triplicates. 


\section{8(a) JC- 1 staining}

\section{Group 1}

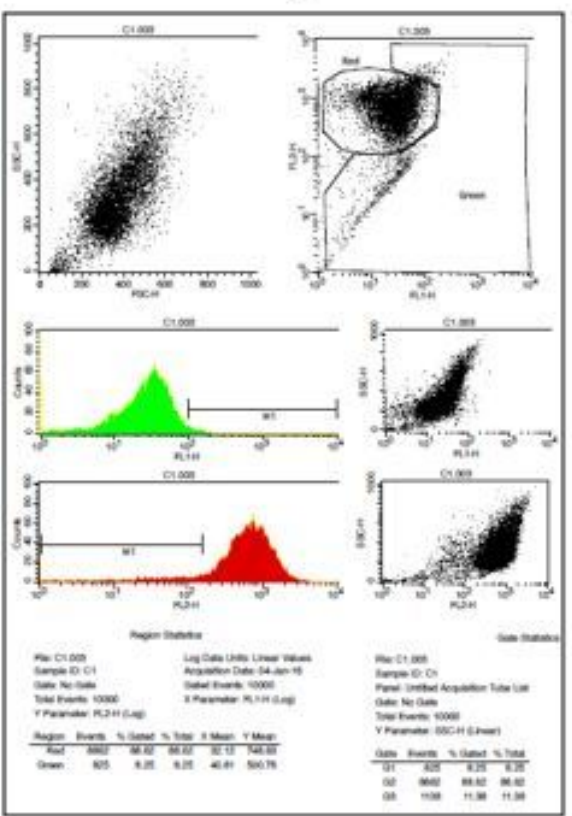

\section{Group 1}

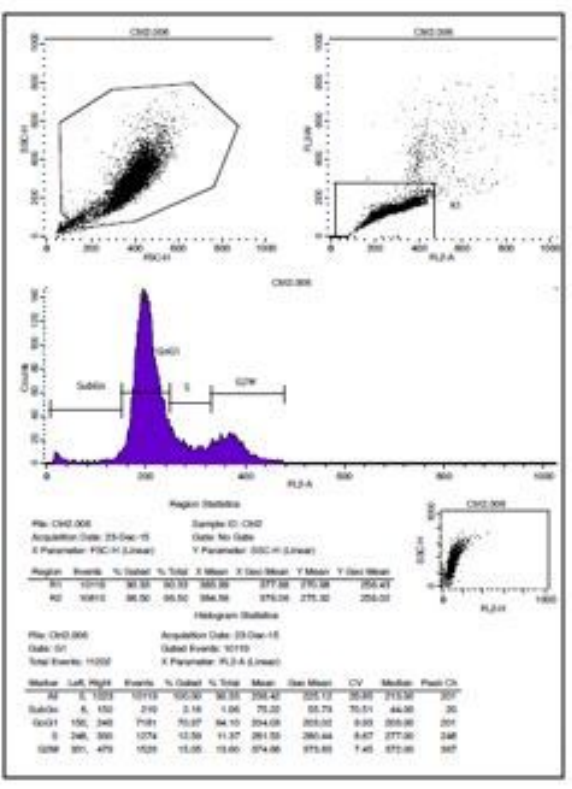

Group 2

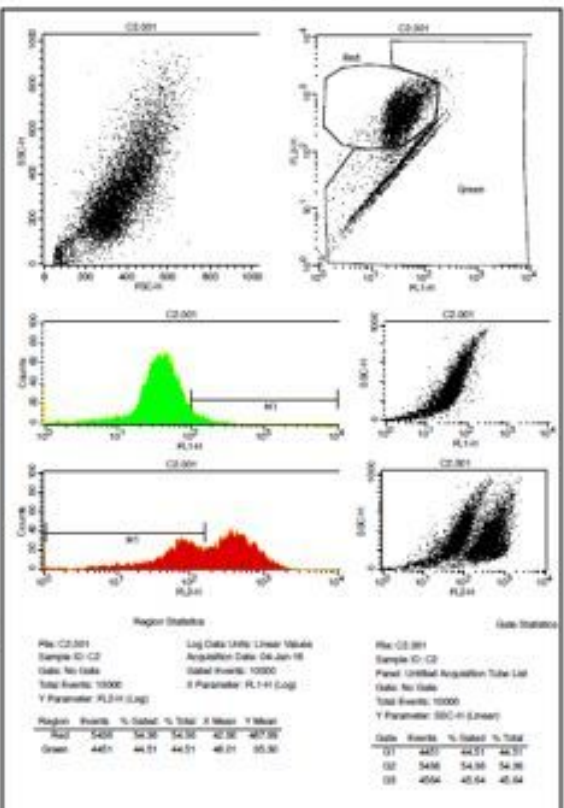

\section{Group 3}

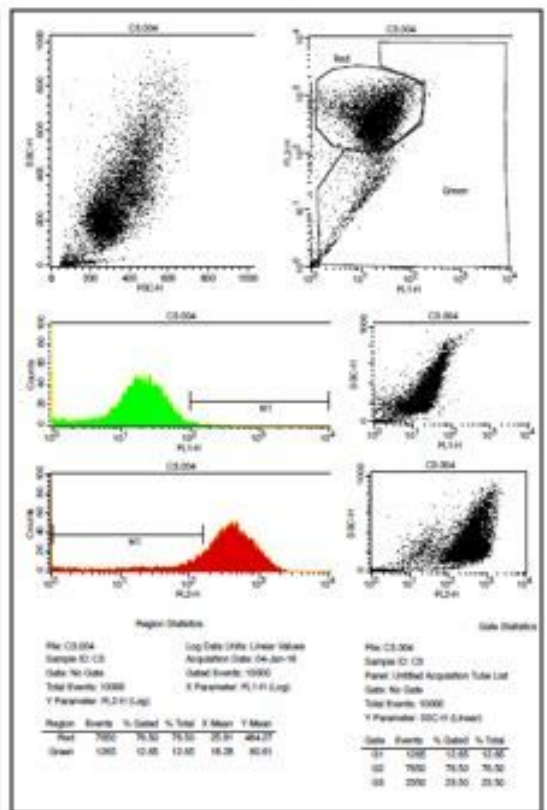

\section{8(b) Cell cycle analysis}

\section{Group 2}

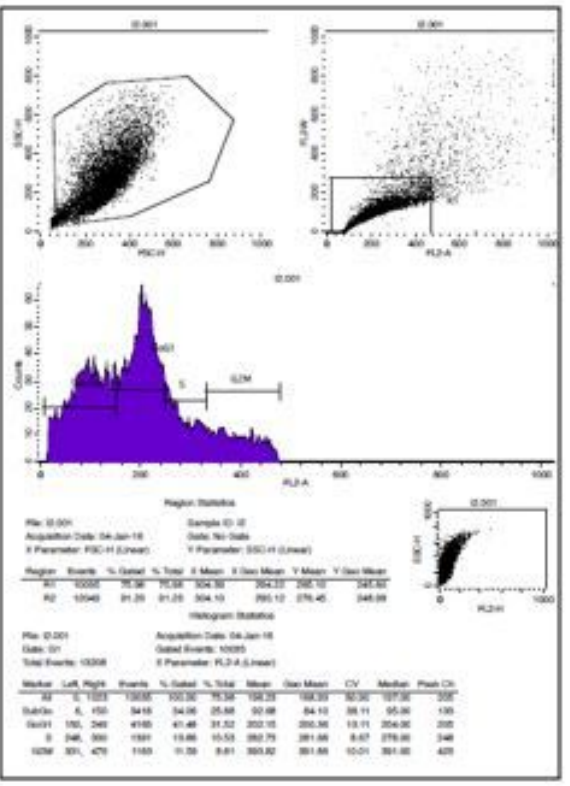

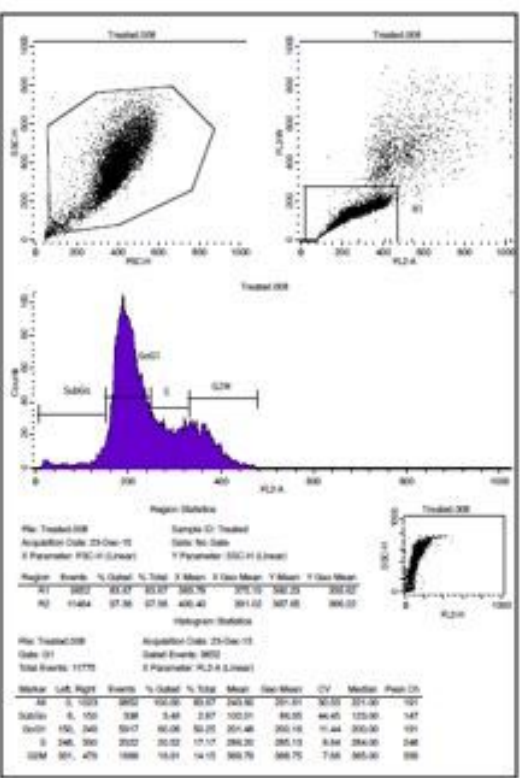

Group 3

Figure 8

Flow cytometric analysis of control and experimental groups. (a) Represents JC-1 dye staining to assess the mitochondrial membrane potential of control and experimental groupings. (b) Cell cycle analysis of control and experimental groupings using PI stain. 


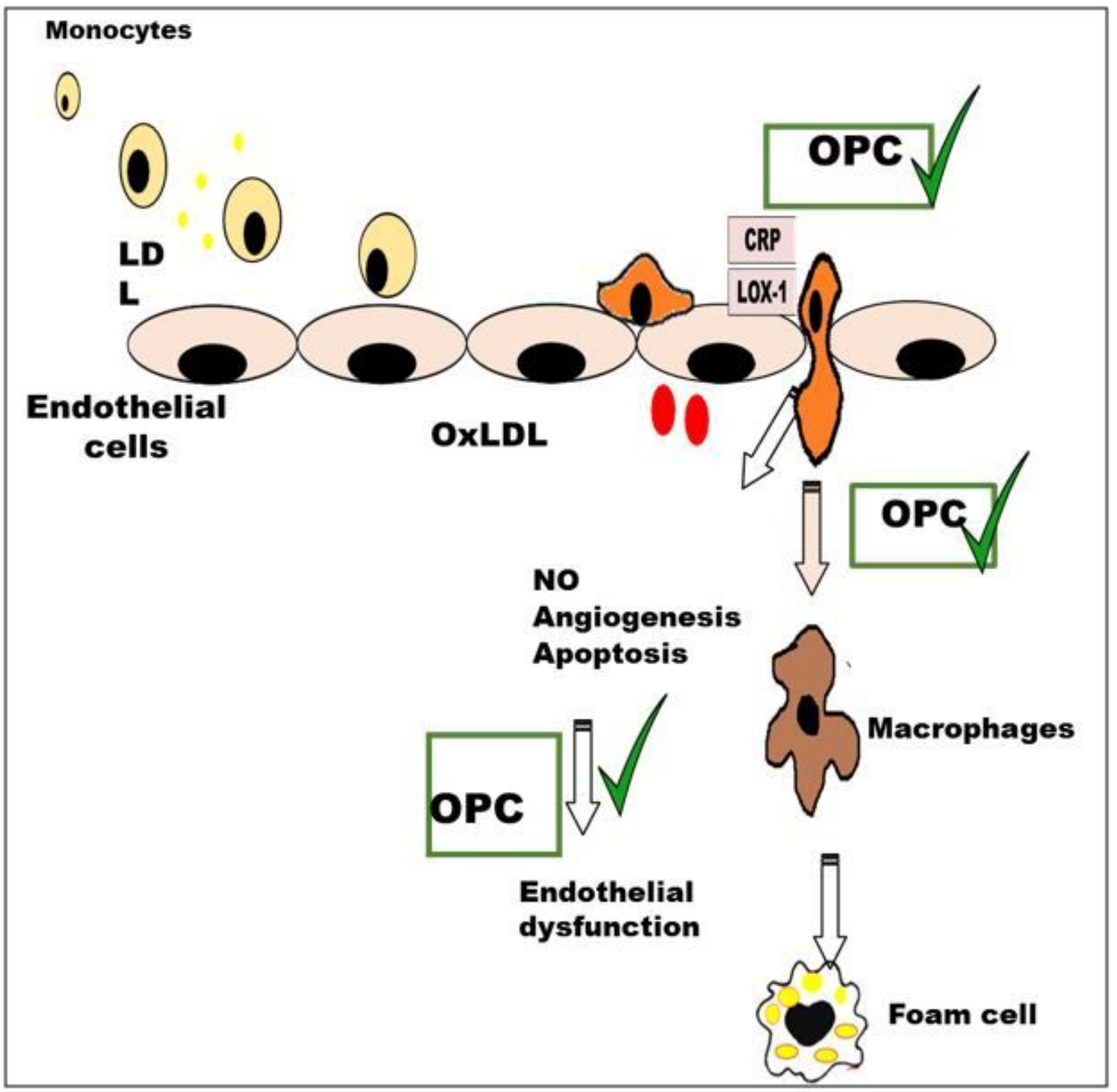

Figure 9

Summary of the possible intervention of OPC against CRP and OXLDL mediated endothelial dysfunction. 